\title{
CORRECTION TO: GRAVITY IN THE STATUTE OF THE INTERNATIONAL CRIMINAL COURT AND CYBER CONDUCT THAT CONSTITUTES, INSTIGATES OR FACILITATES INTERNATIONAL CRIMES
}

Correction to: Criminal Law Forum https://doi.org/10.1007/s10609-019-09370-0

In the original publication, the affiliation of corresponding author Prof. Marco Roscini was published incorrectly.

The correct affiliation should read as "Marco Roscini is Professor of International Law, Westminster Law School, University of Westminster".

And in the footnote 60, the last sentence should read as "See Robert Fanelli and Gregory Conti, "A Methodology for Cyber Operations Targeting and Control of Collateral Damage in the Context of Lawful Armed Conflict", in Christian Czosseck, Rain Ottis, and Katharina Ziolkowski (eds.), 2012 4th International Conference on Cyber Conflict (CCDCOE, 2012), pp. 323-4".

Publisher's Note Springer Nature remains neutral with regard to jurisdictional claims in published maps and institutional affiliations.

\footnotetext{
* Marco Roscini is Professor of International Law, Westminster Law School, University of Westminster.

The original article can be found online at https://doi.org/10.1007/s10609-01909370-0.
} 